\title{
APPLICATION OF THE RANDOM AMPLIFIED POLYMORPHIC DNA USING THE POLYMERASE CHAIN REACTION FOR EFFICIENT ELIMINATION OF DUPLICATE STRAINS IN MICROBIAL SCREENING
}

II. ACTINOMYCETES

\author{
Yojiro Anzai, Toru Okuda and Junko Watanabe* \\ Department of Microbiology and Taxonomy, \\ Nippon Roche Research Center, \\ 200 Kajiwara, Kamakura, Kanagawa 247, Japan \\ (Received for publication September 27, 1993)
}

\begin{abstract}
We evaluated the random amplified polymorphic DNA (RAPD) method using Streptomyces lavendulae and Streptomyces virginiae strains to eliminate duplicate actinomycete strains in our microbial screening program. The RAPD data were compared with phenotypic characteristics, DNA relatedness, HPLC analysis of metabolites and low-frequency restriction fragment analysis by pulsed-field gel electrophoresis. These results were consistent with each other. Therefore, we conclude that RAPD is a simple, efficient, and reliable method for the selection of actinomycete strains.
\end{abstract}

A large number of actinomycete strains isolated and selected empirically by taxonomists, have been subjected to microbial screenings. For improving the efficiency of screenings we need a method that could eliminate strains, particularly similar ones isolated from different samples.

Low-frequency restriction fragment analysis (LFRFA) of DNA by pulsed-field gel electrophoresis (PFGE) as a relatively new technique for analysing large DNA fragments has recently proved to be useful for identifying genetic variation of microorganisms ${ }^{1,2}$. It has been reported that mutants and variants of Frankia strains generally clustered closely with their parents ${ }^{3)}$.

The random amplified polymorphic DNA (RAPD) method is a DNA polymorphism analysis system based on the amplification of random DNA segments with single primers of arbitrary nucleotide sequence. These primers detect polymorphisms in the absence of specific nucleotide sequence information ${ }^{4,5)}$.

We applied this method to evaluate actinomycete strains. In this study, we used Streptomyces lavendulae and Streptomyces virginiae strains which have been reported as producers of many kind of bioactive compounds and frequently isolated from soil samples. Moreover, $S$. virginiae has been given as a subjective synonym of $S$. lavendulae by $\mathrm{S}$. T. WILLIAMs ${ }^{6)}$.

\section{Materials and Methods}

Microorganisms

Actinomycete strains used in this study are shown in Table 1. They were purchased from the Institute for Fermentation, Osaka, Japan, (IFO), American Type Culture Collection, Rockville, U.S.A., (ATCC), and Japan Collection of Microorganisms, Saitama, Japan, (JCM).

Cultural and Physiological Tests

Methods adopted by the International Streptomyces Project (ISP) ${ }^{7)}$ were used for our taxonomic studies. Activities of 19 enzymes were assayed by the API ZYM system (API System S. A.). Strains were 
tested for their susceptibility against antibiotics (gentamicin (GM), lincomycin (LCM), oleandomycin (OM), benzylpenicillin (PCG)) using Tridisk 'Eiken' (Eiken chemical Co., Ltd.). Susceptibility to antibiotics was scored as positive. Antimicrobial activity of the strains against Bacillus subtilis PCI 219 was detected by a disk assay method using their broth cultured in a liquid medium consisting of $2.0 \%$ potato starch, $2.0 \%$ glucose, $0.5 \%$ yeast extract, $2.0 \%$ Toast soya, $0.25 \% \mathrm{NaCl}, 0.005 \% \mathrm{ZnSO}_{4}$. $7 \mathrm{H}_{2} \mathrm{O}, 0.0005 \% \mathrm{CuSO}_{4} \cdot 5 \mathrm{H}_{2} \mathrm{O}, 0.0005 \% \mathrm{MnCl}_{2}$. $4 \mathrm{H}_{2} \mathrm{O}$ and $\mathrm{CaCO}_{3} 0.32 \%(\mathrm{pH} 7.0$ ).

\section{DNA - DNA Hybridization}

DNA was extracted from the cells by the method of MARMUR ${ }^{8}$. The extent of DNA homology between strains was determined by the fluorometric DNA hybridization method using photobiotin in microdilution wells described by EZAKI $^{9)}$. Hybridization was carried out for 2 hours at $55^{\circ} \mathrm{C}$
Table 1. Strains tested.

\begin{tabular}{ll}
\hline \multicolumn{1}{c}{ Strain } & \multicolumn{1}{c}{$\begin{array}{c}\text { Culture } \\
\text { collection } \\
\text { reference No. }\end{array}$} \\
\hline $\begin{array}{l}\text { Streptomyces lavendulae subsp. } \\
\text { lavendulae }\end{array}$ & IFO 3125 \\
S. lavendulae subsp. lavendulae & IFO 3145 \\
S. lavendulae subsp. lavendulae & IFO 3361 \\
S. lavendulae subsp. lavendulae & IFO 12340 \\
S. lavendulae subsp. lavendulae & IFO 12341 \\
S. lavendulae subsp. lavendulae & IFO 12343 \\
S. lavendulae subsp. lavendulae & IFO 12344 \\
S. lavendulae subsp. lavendulae & IFO 13710 \\
S. lavendulae subsp. fuscus & IFO 14028 \\
S. lavendulae subsp. lavendulae & IFO 13709 \\
S. lavendulae subsp. lavendulae & IFO $12789^{\mathrm{T}}$ \\
S. virginiae subsp. lipoxae & JCM 4724 \\
S. virginiae & IFO 3392 \\
S. virginiae & IFO 3729 \\
S. virginiae & ATCC 13013 \\
S. virginiae & ATCC 13161 \\
S. virginiae & ATCC 15894 \\
S. virginiae & IFO $12827^{\mathrm{T}}$ \\
\hline
\end{tabular}

Analysis of Metabolites by HPLC

Each strain was cultured in a $500-\mathrm{ml}$ baffled Erlenmeyer flask containing $100 \mathrm{ml}$ of the same medium as described above on a rotary shaker at $27^{\circ} \mathrm{C}$ for 5 days at $220 \mathrm{rpm}$. The culture broth was extracted with ethyl acetate. The ethyl acetate layer was separated and concentrated under reduced pressure. The residue was dissolved in methanol and chromatographed according to the method of FRISVAD ${ }^{10)}$. A Waters HPLC system 600E with a PDA detector was used. The UV detector was set to monitor at 200, 225 , and $254 \mathrm{~nm}$. Samples $(20 \mu \mathrm{l})$ were injected with a Waters autosampler injection system. Analyses were performed on a $150 \times 4.6 \mathrm{~mm}$ ODS $\mathrm{C}_{18}$ column (YMC pack A301). A gradient solvent system (with solvent $\mathrm{A}=$ water and solvent $\mathbf{B}=0.05 \%$ trifluoroacetic acid in acetonitrile) was used. The gradient program was as follows: the initial percentage of solvent $\mathrm{B}$ was $10 \%$, which was raised to $50 \%$ in 30 minutes, then to $90 \%$ in 10 minutes, held at $90 \%$ for 10 minutes and lowered to $10 \%$ again in 3 minutes, and held at $10 \%$ for 2 minutes at a flow-rate of $2.0 \mathrm{ml} /$ minute until the next injection occurs.

\section{LFRFA by PFGE}

A slant culture of strain was inoculated into $100 \mathrm{ml} \mathrm{YG}$ broth consisting of $1 \%$ yeast extract and $1 \%$ glucose $(\mathrm{pH} 7.2)$ in a $500-\mathrm{ml}$ baffled Erlenmeyer flask and incubated on a rotary shaker at $27^{\circ} \mathrm{C}$ for 3 days at $220 \mathrm{rpm}$. Two $\mathrm{ml}$ of this culture was transferred into $100 \mathrm{ml}$ of $\mathrm{YG}$ broth supplemented with $0.1 \%$ glycine and incubated overnight on a rotary shaker under the same conditions as described above. Washed mycelia from the resulting culture were embedded in $0.5 \%$ agarose. The preparation of the agarose plug was carried out according to the methods of LEBLOND ${ }^{1)}$ and KIESER ${ }^{11}$. After treatment with proteinase $\mathrm{K}$ (Merck), the plug was incubated in TE buffer (10 mM Tris-HCl, $1 \mathrm{mM}$ EDTA, pH 8.0) containing $0.1 \mathrm{~mm}$ ( $p$-amidinophenyl) methanesulfonyl fluoride hydrochloride (Wako Pure Chemical Co., Ltd.) for 1 hour at $4^{\circ} \mathrm{C}$ to inhibit protease. The plugs were stored at $4^{\circ} \mathrm{C}$ in NDS buffer $(0.5 \mathrm{M}$ EDTA, $10 \mathrm{~mm}$ Tris-HCl (pH 9.0), 1\% (w/v) lauroyl sarcosine).

To digest the DNA, the plug was soaked in $1 \times$ restriction enzyme buffer (Takara) for 15 minutes. The buffer was removed, replaced with $200 \mu \mathrm{l}$ of fresh buffer, and $5 \mu \mathrm{l}$ of bovine serum albumin $(0.1 \%$; Takara) and a restriction enzyme were added. Fifty unit of DraI (Takara) and VspI (Takara), and 2.5 unit of $S s p$ I (Takara) were incubated as described by KIESER ${ }^{11)}$.

PFGE was performed by using a $1 \%$ agarose gel in $0.5 \times$ Tris-borate buffer $(1 \times$ TBE contains $89 \mathrm{~mm}$ Tris, $89 \mathrm{~mm}$ boric acid, and $2 \mathrm{~mm}$ EDTA (pH 8.0)) in the Bio-Rad CHEF DR-II System. The running buffer was $0.5 \times \mathrm{TBE}$ held at $14^{\circ} \mathrm{C}$. The following program was used for $200-$ to $2,000-\mathrm{kb}$ fragments: 
15 hours at $200 \mathrm{~V}$ with 60 second pulses, and 9 hours at $200 \mathrm{~V}$ with 90 second pulses. For $50-$ to $1,000-\mathrm{kb}$ fragments the following program was used: 24 hours at $200 \mathrm{~V}$ with 50 to 90 second gradient pulses. The size standards used for the DNA bands at the higher molecular weights were Saccharomyces cerevisiae (strain YNN295) chromosomes, and lambda concatemers were the standards used for the lower molecular weight range, both from Bio-Rad. After electrophoresis, gels were stained with ethidium bromide.

Amplification and Electrophoresis Condition for RAPD

Amplification conditions were modified from those of WILLIAMs $^{12)}$ and GoodwIN ${ }^{13)}$. The amplification reaction mixture $(50 \mu \mathrm{l})$ consisted of $1 \times \operatorname{Taq}$ DNA polymerase buffer (Pro Bio), $200 \mu \mathrm{M}$ each of dATP, dCTP, dGTP and dTTP (Takara), $2 \mathrm{mM} \mathrm{MgCl}_{2} 50 \mathrm{ng}$ of genomic DNA, $2.5 \mu \mathrm{M}$ primer and 4 unit of Taq DNA polymerase (Pro Bio). Amplifications were performed in the ZYMOREACTER II (Atto Co., Ltd.) with following program: initial denaturation at $94^{\circ} \mathrm{C}$ for 2 minutes, 30 or 35 cycles of denaturation at $94^{\circ} \mathrm{C}$ for 1 minute, annealing at $34^{\circ} \mathrm{C}$ for 1 minute, extension at $72^{\circ} \mathrm{C}$ for 2 minutes, and final extension at $72^{\circ} \mathrm{C}$ for 10 minutes. We used 12 primers, R28 (5'-ATGGATCCGC), B1 (5'-TCACGATGCA), and $\mathrm{B} 2$ to $\mathrm{B} 11$ which differed from $\mathrm{B} 1$ by substitution of a single nucleotide at a successive position in the sequence. The $\mathrm{G}+\mathrm{C}$ content of primers $\mathrm{B} 2$ to $\mathrm{B} 11$ was maintained at $50 \%$. All primers were synthesized on an Applied Biosystems Model 392 DNA synthesizer.

Electrophoresis of polymerase chain reaction (PCR) products was carried out according to FuJIMORI and OKUDA ${ }^{14)}$.

\section{Data Analysis}

Image analysis of the electrophoretic band patterns of RAPD and the conversion of Rf values of each band to the 0-1 matrix data were carried out according to the method of FUJMORI and OKUDA ${ }^{14)}$. Cluster analysis was achieved by the use of the phylogenetic inference package, PAUP (phylogenetic analysis using parsimony) ${ }^{15}$.

\section{Results}

\section{Taxonomic Characteristics}

Morphological, cultural and physiological characteristics of 18 strains are shown in Table 2. All strains except for $S$. lavendulae subsp. fuscus IFO 14028 formed pale pinkish gray aerial mycelium. All strains hydrolyzed starch and showed antibiosis against B. subtilis PCI 219. All strains except for $S$. lavendulae subsp. lavendulae IFO 3361 produced melanoid pigments. The carbohydrate utilization and the enzymatic activity are shown in Tables 3 and 4, respectively. Regarding physiology, therefore, S. lavendulae subsp. lavendulae IFO 3361 and IFO 12341 and S. virginiae ATCC 13013 showed different characteristics from those of other strains.

The data in Tables 2, 3, and 4 were used for the cluster analysis with the PAUP. The dendrogram was generated by using the branch and bound algorithm (Fig. 1).

S. lavendulae subsp. lavendulae IFO 12343, IFO 12344, IFO 13710 and IFO $12789^{\mathrm{T}}$ were located in the same cluster. S. virginiae subsp. lipoxae JCM 4724, S. virginiae IFO 3392 and ATCC 15894 formed another cluster. S. virginiae IFO 3729 and IFO $12827^{\mathrm{T}}$ were also placed in the third cluster. While, S. lavendulae subsp. lavendulae IFO 3361 and IFO 12341 and S. virginiae ATCC 13013 were located in a distinct cluster far from the other strains.

\section{DNA Relatedness}

The DNA relatedness between S. lavendulae subsp. lavendulae IFO $12789^{\mathrm{T}}$ and the other strains, and between $S$. virginiae IFO $12827^{\mathrm{T}}$ and the other strains are shown in Table 5.

The homology value between S. lavendulae subsp. lavendulae IFO $12789^{\mathrm{T}}$ and S. virginiae IFO $12827^{\mathrm{T}}$ 
Table 2. Morphological, cultural and physiological characteristics of 18 strains of Streptomyces lavendulae and Streptomyces virginiae.

\begin{tabular}{|c|c|c|c|c|c|c|c|c|c|c|c|c|c|c|c|c|c|c|}
\hline \multirow{2}{*}{ Test } & \multicolumn{18}{|c|}{ Strain No. ${ }^{a}$} \\
\hline & 1 & 2 & 3 & 4 & 5 & 6 & 7 & 8 & 9 & 10 & 11 & 12 & 13 & 14 & 15 & 16 & 17 & 18 \\
\hline Spore chain morphology & RA & RA & RA & RA & $\mathrm{RF}$ & RA & RA & RA & RA & RA & RA & RA & RA & RA & RA & RA & RA & RA \\
\hline Spore mass color & PG & PG & PG & PG & PG & PG & PG & PG & B & PG & PG & PG & $P G$ & PG & PG & PG & PG & PG \\
\hline Gelatin liquefaction at $20^{\circ} \mathrm{C}$ & - & - & + & - & + & - & - & - & - & - & - & - & - & - & - & - & - & - \\
\hline at $27^{\circ} \mathrm{C}$ & - & - & + & - & + & - & - & - & - & - & - & - & - & - & - & - & - & - \\
\hline Starch hydrolysis & + & + & + & + & + & + & + & + & + & + & + & + & + & + & + & + & + & + \\
\hline Milk coagulation at $27^{\circ} \mathrm{C}$ & - & - & - & - & - & - & - & - & - & - & - & - & - & - & - & - & - & - \\
\hline at $37^{\circ} \mathrm{C}$ & - & - & + & - & + & - & - & - & - & - & - & - & - & - & + & - & - & - \\
\hline Milk peptonization at $27^{\circ} \mathrm{C}$ & + & + & + & + & + & + & + & - & - & - & + & - & - & + & - & - & - & + \\
\hline at $37^{\circ} \mathrm{C}$ & + & - & + & - & + & - & - & - & - & - & - & - & - & + & + & - & - & + \\
\hline Nitrate reduction & + & + & - & + & - & - & - & - & - & + & - & - & - & - & - & + & - & - \\
\hline Melanin production: ISP 1 & + & + & - & \pm & + & \pm & + & + & + & + & \pm & \pm & \pm & + & + & + & + & + \\
\hline ISP 6 & + & + & - & $\overline{+}$ & + & $\bar{t}$ & + & + & + & + & $\bar{t}$ & + & + & + & + & + & + & + \\
\hline ISP 7 & + & + & - & \pm & + & + & + & + & + & + & + & + & \pm & + & + & + & + & + \\
\hline $\mathrm{NaCl}$ tolerance $(\%)$ & 5 & 4 & 7 & $\overline{4}$ & 7 & 5 & 5 & 5 & 1 & 4 & 5 & 5 & $\overline{3}$ & 5 & 7 & 5 & 5 & 4 \\
\hline Growth at $5^{\circ} \mathrm{C}$ & - & - & - & - & + & + & + & - & - & - & + & + & + & - & - & + & + & - \\
\hline $\begin{array}{c}\text { at } 40^{\circ} \mathrm{C} \\
\text { Antibiotic susceptibility: }\end{array}$ & + & + & + & - & - & - & - & - & + & - & - & - & - & - & + & - & - & - \\
\hline $\mathrm{GM}(2 \mu \mathrm{g} / \mathrm{ml})$ & + & - & + & - & + & + & + & + & + & + & + & + & + & + & + & + & + & + \\
\hline $\mathrm{LCM}(15 \mu \mathrm{g} / \mathrm{ml})$ & + & + & - & + & + & + & + & + & + & + & + & + & + & + & - & - & + & + \\
\hline $\mathrm{OM}(5 \mu \mathrm{g} / \mathrm{ml})$ & + & + & - & + & - & + & + & + & + & + & + & + & + & + & - & + & + & + \\
\hline PCG $(10 \mathrm{v} / \mathrm{ml})$ & - & - & - & - & - & - & - & - & + & - & - & - & - & - & - & - & - & - \\
\hline $\begin{array}{l}\text { Antibiosis ag. B. subtilis PCI } \\
219\end{array}$ & + & + & + & + & + & + & + & + & + & + & + & + & + & + & + & + & + & + \\
\hline
\end{tabular}

RA, Retinaculiaperti; RF, Rectiflexibiles; PG, pinkish gray; B, brown

Numbers 1 to 11 are $S$. lavendulae strains and numbers 12 to 18 are $S$. virginiae strains. 1, IFO 3125; 2, IFO 3145; 3, IFO 3361; 4, IFO 12340; 5, IFO 12341; 6, IFO 12343; 7, IFO 12344; 8, IFO 13710; 9, IFO 14028; 10, IFO 13709; 11, IFO 12789'; 12, JCM 4724; 13, IFO 3392; 14, IFO 3729; 15, ATCC 13013; 16, ATCC 13161; 17, ATCC $15894 ; 18$, IFO $12827^{\mathrm{T}}$. 
Table 3. Carbohydrate utilization of 18 strains of Streptomyces lavendulae and Streptomyces virginiae.

\begin{tabular}{|c|c|c|c|c|c|c|c|c|c|c|c|c|c|c|c|c|c|c|}
\hline \multirow{2}{*}{ Carbohydrate } & \multicolumn{18}{|c|}{ Strain No. ${ }^{a}$} \\
\hline & 1 & 2 & 3 & 4 & 5 & 6 & 7 & 8 & 9 & 10 & 11 & 12 & 13 & 14 & 15 & 16 & 17 & 18 \\
\hline L-Arabinose & + & + & + & + & - & - & - & \pm & - & - & - & + & $t$ & - & + & - & + & - \\
\hline D-Fructose & + & + & + & + & + & + & + & + & + & + & $t$ & + & + & + & + & + & + & + \\
\hline D-Glucose & + & + & + & + & + & + & + & + & + & + & + & + & + & + & + & + & + & + \\
\hline Inositol & - & - & + & - & - & - & - & - & - & - & - & - & - & - & + & - & - & - \\
\hline D-Mannitol & - & - & + & - & + & - & - & - & - & - & - & - & - & - & + & - & - & - \\
\hline Melezitose & - & - & - & - & - & + & + & + & - & - & + & - & - & - & - & - & - & - \\
\hline Melibiose & - & - & - & - & - & - & - & - & - & - & - & - & - & - & - & - & - & - \\
\hline Raffinose & - & - & - & - & $\ldots$ & - & - & - & - & - & - & - & - & - & - & - & - & - \\
\hline L-Rhamnose & - & - & + & - & + & - & - & - & - & - & - & - & - & - & + & - & - & - \\
\hline Sucrose & + & - & - & - & \pm & - & - & - & + & - & - & - & - & - & \pm & - & - & - \\
\hline D-Xylose & + & - & + & + & + & - & - & - & - & - & - & + & - & - & + & - & - & - \\
\hline
\end{tabular}

a Numbers 1 to 11 are $S$. lavendulae strains and numbers 12 to 18 are $S$. virginiae strains. 1, IFO 3125; 2, IFO 3145; 3, IFO 3361, 4, IFO 12340; 5, IFO 12341; 6, IFO 12343; 7, IFO 12344; 8, IFO 13710; 9, IFO 14028; 10, IFO 13709; 11, IFO 12789 ; 12, JCM 4724; 13, IFO 3392; 14, IFO 3729; 15, ATCC 13013; 16, ATCC 13161; 17, ATCC $15894 ; 18$, IFO $12827^{\mathrm{T}}$.

Table 4. Enzymatic activity in 18 strains of Streptomyces lavendulae and Streptomyces virginiae.

\begin{tabular}{|c|c|c|c|c|c|c|c|c|c|c|c|c|c|c|c|c|c|c|}
\hline \multirow{2}{*}{ Enzyme assayed for } & \multicolumn{18}{|c|}{ Strain No. ${ }^{a}$} \\
\hline & 1 & 2 & 3 & 4 & 5 & 6 & 7 & 8 & 9 & 10 & 11 & 12 & 13 & 14 & 15 & 16 & 17 & 18 \\
\hline Alkaline phosphatase & + & + & + & + & + & + & + & + & + & + & + & + & + & + & + & + & + & + \\
\hline Esterase (butyrate) & + & + & + & + & + & + & + & + & + & + & + & + & + & + & + & + & + & + \\
\hline Esterase (caprylate) & + & + & + & + & + & + & + & + & + & + & + & + & + & + & + & + & + & + \\
\hline Lipase (myristate) & + & + & + & + & - & + & + & + & + & + & + & - & - & + & + & + & - & + \\
\hline Leucine arylamidase & + & + & + & + & + & + & + & + & + & + & + & + & + & + & + & + & + & + \\
\hline Valine arylamidase & + & + & + & + & + & + & + & + & + & + & + & + & + & + & + & + & + & + \\
\hline Cystine arylamidase & + & + & + & + & + & + & + & + & + & + & + & + & + & + & + & + & + & + \\
\hline Trypsin & + & + & + & + & + & - & - & - & + & + & - & + & + & + & + & + & + & - \\
\hline$\alpha$-Chymotrypsin & + & + & + & + & + & + & + & + & + & + & + & + & + & + & + & + & + & + \\
\hline Acid phosphatase & + & + & + & + & + & + & + & + & + & + & + & + & + & + & + & + & + & + \\
\hline Phosphoamidase & + & + & + & + & + & + & + & + & + & + & + & + & + & + & + & + & + & + \\
\hline$\alpha-\mathrm{D}-$ Galactosidase & - & - & - & - & - & - & - & - & - & - & - & - & - & - & - & - & - & - \\
\hline$\beta$-D-Galactosidase & - & - & + & - & + & - & - & - & - & - & - & + & + & + & + & - & + & + \\
\hline$\beta$-D-Glucuronidase & - & - & - & - & - & - & - & - & - & - & - & - & - & - & - & - & - & - \\
\hline$\alpha$-D-Glucosidase & + & + & + & + & + & + & + & + & - & + & + & + & + & + & + & + & + & + \\
\hline$\beta$-D-Glucosidase & + & + & + & + & + & + & + & + & - & + & + & + & + & + & - & + & + & + \\
\hline $\begin{array}{l}N \text {-Acetyl- } \beta \text {-D- } \\
\text {. glucosaminidase }\end{array}$ & + & + & + & + & + & + & + & + & + & + & + & + & + & + & + & + & $t$ & + \\
\hline$\alpha$-D-Mannosidase & - & + & + & + & - & + & + & + & - & - & + & + & $t$ & + & + & + & + & + \\
\hline$\alpha$-L-Fucosidase & - & - & - & - & + & - & - & - & - & - & - & - & - & - & - & - & - & - \\
\hline
\end{tabular}

a Numbers 1 to 11 are $S$. lavendulae strains and numbers 12 to 18 are $S$. virginiae strains. 1, IFO $3125 ; 2$, IFO 3145 ; 3, IFO 3361; 4, IFO 12340; 5, IFO 12341; 6, IFO 12343; 7, IFO 12344; 8, IFO 13710; 9 , IFO 14028; 10, IFO $13709 ; 11$, IFO $12789^{\mathrm{T}}$; 12, JCM 4724; 13, IFO 3392; 14, IFO 3729; 15, ATCC 13013; 16, ATCC 13161; 17, ATCC $15894 ; 18$, IFO $12827^{\mathrm{T}}$.

was low $(31 \sim 36 \%)$.

The homology values between S. lavendulae subsp. lavendulae IFO $12789^{\mathrm{T}}$ and IFO 12343, IFO 12344 and IFO 13710 were very high $(97 \%, 67 \%$ and $103 \%$, respectively). Furthermore, the homology values between $S$. virginiae IFO $12827^{\mathrm{T}}$ and $S$. lavendulae subsp. lavendulae IFO 13709 , and S. virginiae IFO 3729 were also very high ( $84 \%$ and $107 \%$, respectively). The DNA relatedness results between these strains 
except for S. lavendulae subsp. lavendulae IFO 13709 agreed well with those of the previous cluster analysis. On the other hand, the homology values between 2 type strains and $S$. lavendulae subsp. lavendulae IFO 3361, IFO 12341 and $S$. virginiae ATCC 13013 were very low. These strains were located in a cluster far

Fig. 1. Dendrogram for phenotypic data of 18 strains of Streptomyces lavendulae and Streptomyces virginiae.

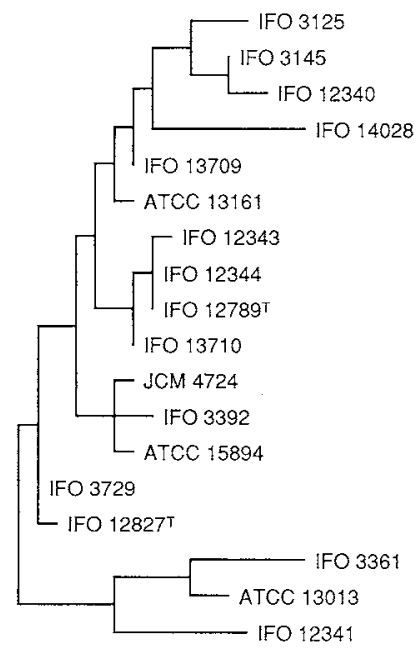

This dendrogram was based on the data of Tables 2, 3 and 4 and solved by the branch and bound method contained within the PAUP (phylogenetic analysis using parsimony) phylogenetic inference package. from the other strains (Fig. 1).

HPLC Profiles of Metabolites

The metabolites of each strains were analyzed by HPLC. A similar chromatogram was observed for S. lavendulae subsp. lavendulae IFO 12343 and IFO 12344 (Fig. 2). The UV spectra (190 to $400 \mathrm{~nm}$ ) of the major peak were identical. HPLC elution profiles of S. virginiae IFO 3392 and ATCC 15894 were also similar to each other. These strains generated two distinct clusters according to the phenotypic data.

\section{LFRFA}

LFRFA using rare-cutting enzymes DraI, $V_{s p \mathrm{I}}$ and $S s p$ I was conducted to discriminate 18 strains.

When undigested DNA samples were electrophoresed, extrachromosomal DNA molecules were observed in some strains. Therefore, these DNAs were removed from the agarose plugs by pre-

Table 5. DNA relatedness between type strain and the other strains.

\begin{tabular}{|c|c|c|}
\hline \multirow[b]{2}{*}{ Strain } & \multicolumn{2}{|c|}{$\%$ Homology with photobiotin-labeled DNA } \\
\hline & $\begin{array}{l}\text { S. lavendulae subsp. } \\
\text { lavendulae } \mathrm{IFO} 12789^{\mathrm{T}}\end{array}$ & S. virginiae IFO $12827^{\mathrm{T}}$ \\
\hline $\begin{array}{l}\text { Streptomyces lavendulae subsp. } \\
\text { lavendulae IFO } 3125\end{array}$ & 38 & 32 \\
\hline S. lavendulae subsp. lavendulae IFO 3145 & 28 & 26 \\
\hline S. lavendulae subsp. lavendulae IFO 3361 & 21 & 15 \\
\hline S. lavendulae subsp. lavendulae IFO 12340 & 54 & 30 \\
\hline S. lavendulae subsp. lavendulae IFO 12341 & 22 & 15 \\
\hline S. lavendulae subsp. lavendulae IFO 12343 & 97 & 34 \\
\hline S. lavendulae subsp. lavendulae IFO 12344 & 67 & 28 \\
\hline S. lavendulae subsp. lavendulae IFO 13710 & 103 & 38 \\
\hline S. lavendulae subsp. fuscus IFO 14028 & 43 & 29 \\
\hline S. lavendulae subsp. lavendulae IFO 13709 & 49 & 84 \\
\hline S. lavendulae subsp. lavendulae IFO $12789^{\mathrm{T}}$ & 100 & 31 \\
\hline S. virginiae subsp. lipoxae JCM 4724 & 39 & 48 \\
\hline S. virginiae IFO 3392 & 42 & 49 \\
\hline S. virginiae IFO 3729 & 30 & 107 \\
\hline S. virginiae ATCC 13013 & 19 & 18 \\
\hline S. virginiae ATCC 13161 & 44 & 47 \\
\hline S. virginiae ATCC 15894 & 47 & 46 \\
\hline S. virginiae IFO $12827^{\mathrm{T}}$ & 36 & 100 \\
\hline
\end{tabular}

DNA homology values are expressed as \% of labeled DNA reassociated with heterologous DNA compared with that reassociated with homologous DNA $(100 \%)$. 
Fig. 2. HPLC profiles of metabolites produced by $S$. lavendulae subsp. lavendulae IFO 12343 and IFO 12344 (at $254 \mathrm{~nm}$ ).
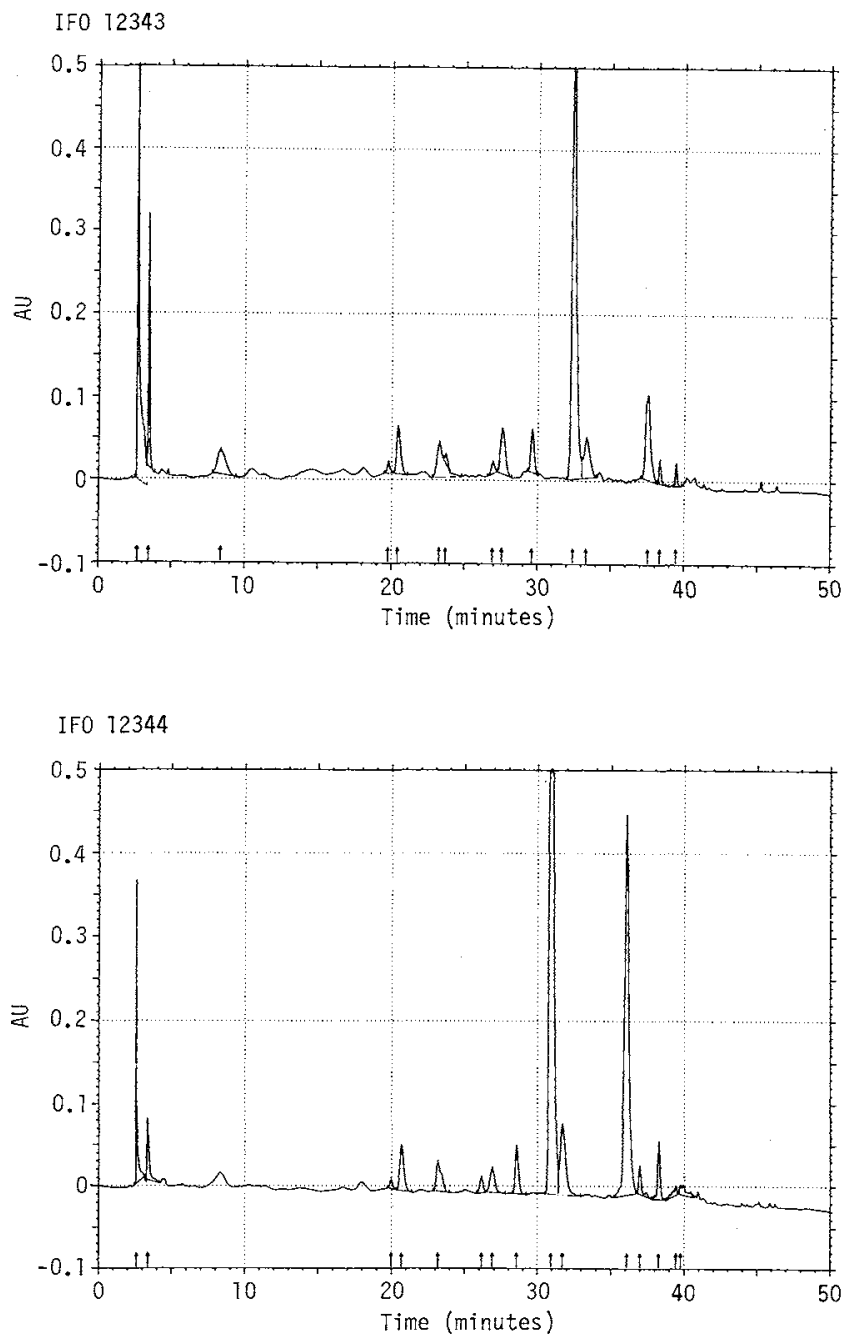

electrophoresis prior to digestion with a restriction enzyme. Fig. 3 shows the restriction patterns of 18 strains using DraI, $V s p \mathrm{I}$ and $S s p \mathrm{I}$. The restriction patterns of $S$. lavendulae subsp. lavendulae IFO 12343 , IFO 12344 and IFO $12789^{\mathrm{T}}$ by 3 restriction enzymes were similar. Those of $S$. virginiae IFO 3392 and ATCC 15894, and S. virginiae IFO 3729 and IFO $12827^{\mathrm{T}}$ were also similar to each other. These results supported the previous phenotypic data, the DNA relatedness and the HPLC profiles of metabolites.

\section{Fingerprinting by RAPD Method}

Genomic fingerprints were generated by the RAPD method. Fig. 4-A shows RAPD patterns of 18 strains using primer R28. Apparently three similar band patterns were observed in several strains. S. lavendulae subsp. lavendulae IFO 12343, IFO 12344 and IFO $12789^{\mathrm{T}}$ possesed almost identical DNA bands. S. virginiae IFO 3392 showed a very similar pattern to that of S. virginiae ATCC 15894. Another almost identical feature was observed in S. virginiae IFO 3729 and IFO $12827^{\mathrm{T}}$. Rf value of each band 
Fig. 3. PFGE of 18 strains of Streptomyces lavendulae and Streptomyces virginiae.

(a) DNAs of strains cut with DraI. S, Saccharomyces cerevisiae chromosomes. (b) DNAs of strains cut with VspI. S, S. cerevisiae chromosomes. (c) DNA of strains cut with SspI. L, lambda concatemers. Lanes 1 to 11 are $S$. lavendulae strains and lanes 12 to 18 are S. virginiae strains. Lane 1, IFO 3125; lane 2, IFO 3145; lane 3, IFO 3361; lane 4, IFO 12340; lane 5, IFO 12341; lane 6, IFO 12343; lane 7, IFO 12344; lane 8, IFO 13710; lane 9, IFO 14028; lane 10, IFO 13709; lane 11, IFO 12789 ${ }^{\mathrm{T}}$; lane 12, JCM 4724; lane 13, IFO 3392; lane 14, IFO 3729; lane 15, ATCC 13013; lane 16, ATCC 13161; lane 17, ATCC 15894; lane 18, IFO $12827^{\mathrm{T}}$.

(a)

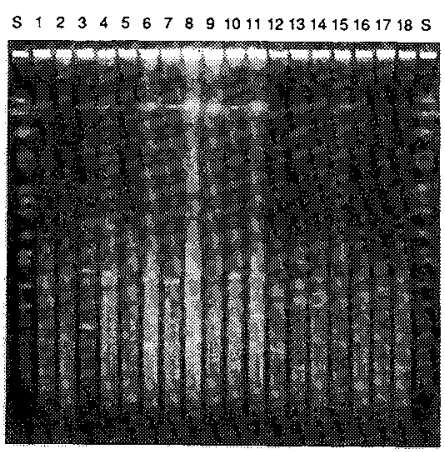

(b)

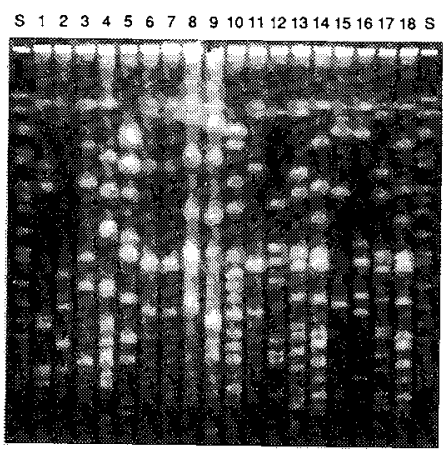

(c)

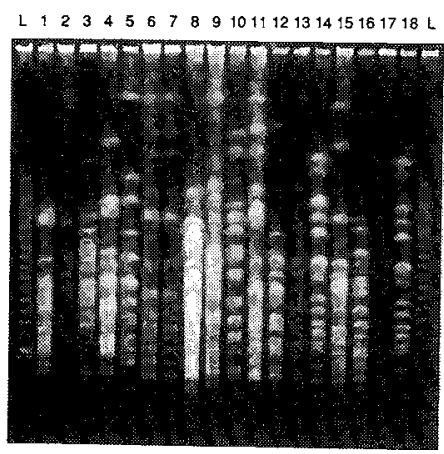

was converted to the 0-1 matrix for analysis with the PAUP. Fig. 5-A shows a dendrogram generated by the bootstrap search option. These strains within 3 groups were located near each other. This result supported the cluster analysis of the phenotypic data, the DNA relatedness, the HPLC profiles of metabolites and the LFRFA.

Fig. 6 shows the RAPD patterns of S. lavendulae subsp. lavendulae IFO 12341 using primers B1 to B11. Similarly crowded band patterns were observed in polymerase chain reaction (PCR) with primers B1 to B3. Primers B4 to B7 decreased the number of bands. Primers B8 to B11 produced a large number of bands and different polymorphisms as compared to the original primer $\mathrm{B} 1$. This tendency was also confirmed in the other strains. Fig. 4-B and 4-C show the RAPD patterns of 18 strains using primers B1 and B9. The dendrogram obtained from primer B9 was similar to that from primer R28. Although the strains within a cluster showed the same band patterns as shown in Fig. 4-B, the dendrogram derived from primer B1 (Fig. 5-B) was different from that of primers R28 and B9. S. lavendulae subsp. lavendulae IFO 12343 and IFO 12344 were located near each other. On the other hand, S. lavendulae subsp. lavendulae IFO $12789^{\mathrm{T}}$ was located a far distance from $S$. lavendulae subsp. lavendulae IFO 12343 and IFO 12344. Furthermore, S. lavendulae subsp. lavendulae IFO 3361 and IFO12340 which showed obviously different band patterns were located near each other.

\section{Discussion}

We evaluated the RAPD method to eliminate duplicate actinomycete strains in this study. Reproducible DNA patterns were produced with all primers. In addition, the dendrograms with the PAUP derived from primers R28 and B9 corresponded well with other analyses (the phenotypic characteristics, the DNA relatedness, the HPLC profiles of metabolites and the LFRFA).

The number of DNA bands observed in each lane and the distribution of DNA bands should be taken into consideration in the selection of an appropriate primer. For example, the numer of DNA bands by primer B1 was less than those by primers R28 and B9, and DNA bands in each lane by primer 
Fig. 4. RAPD patterns of 18 strains of Streptomyces lavendulae and Streptomyces virginiae.

(A), primer R28; (B), primer B1; (C), primer B9. M is pHY marker. The marks of arrowhead (a and $b)$ are $\lambda$-DNA and 90 bp DNA, respectively. Lanes 1 to 11 are $S$. lavendulae strain and lanes 12 to 18 are $S$. virginiae strains. Lane 1 , IFO 3125 ; lane 2 , IFO 3145 ; lane 3 , IFO 3361; lane 4, IFO 12340; lane 5, IFO 12341; lane 6, IFO 12343; lane 7, IFO 12344; lane 8, IFO 13710; lane 9, IFO 14028; lane 10, IFO 13709; lane 11, IFO $12789^{\mathrm{T}}$; lane 12, JCM 4724; lane 13, IFO 3392; lane 14, IFO 3729; lane 15, ATCC 13013; lane 16, ATCC 13161; lane 17, ATCC 15894; lane 18, IFO $12827^{\mathrm{T}}$.

(A)
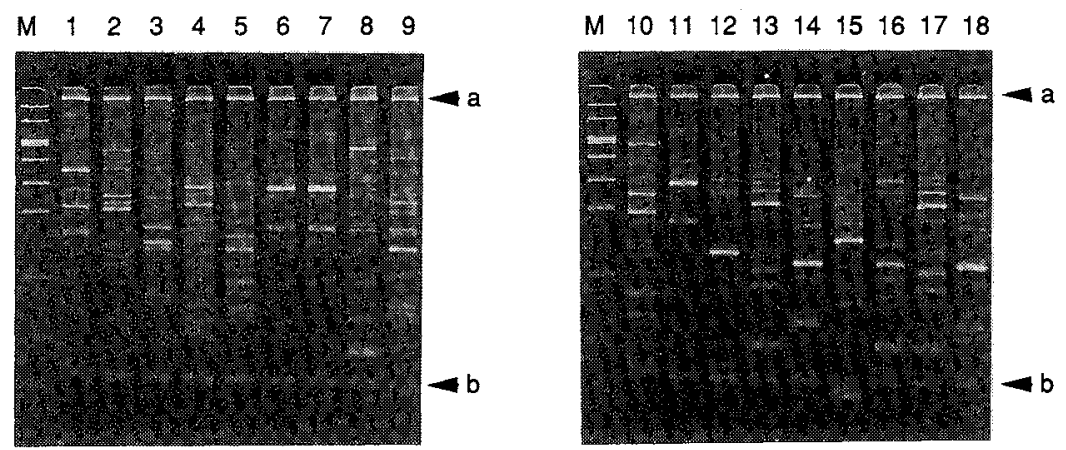

(B)
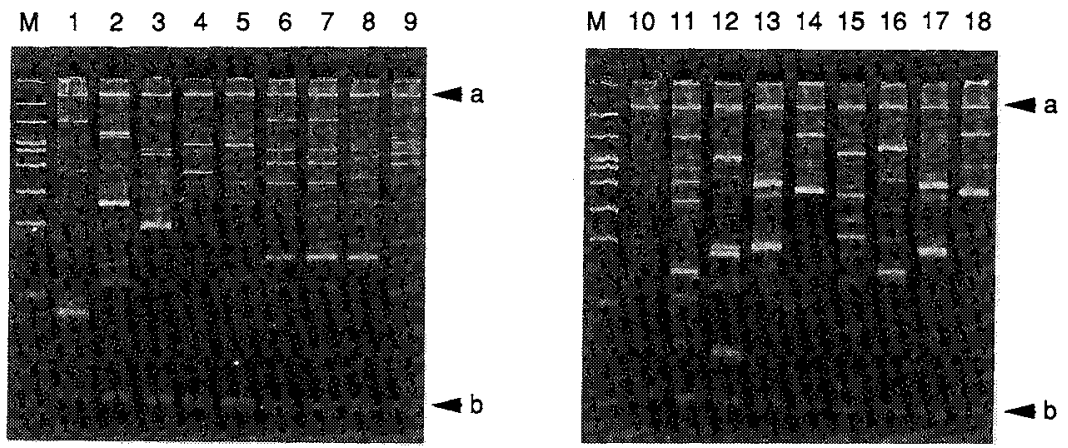

(C)
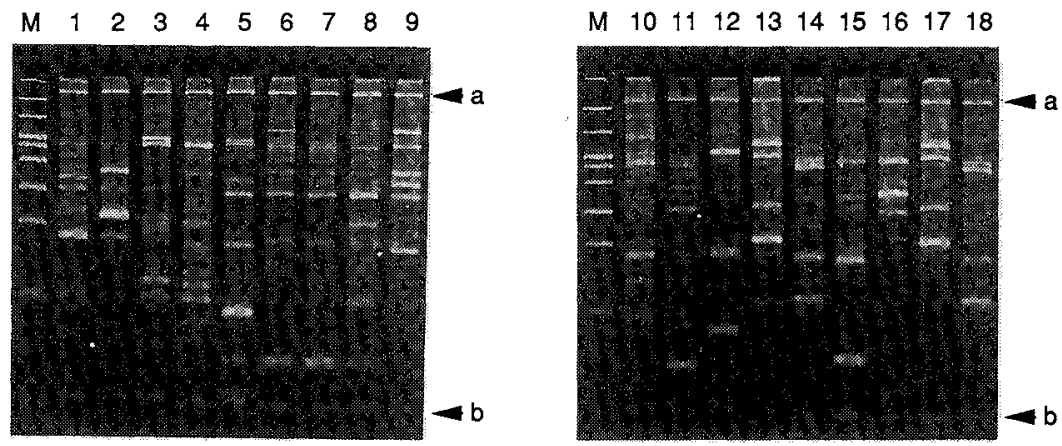

B1 were closely packed together in the upper part of gel ( $\geq 500 \mathrm{bp}, \leq 0.4$ of $\mathrm{Rf}$ ); thus, it might be difficult to measure precise $\mathrm{Rf}$ values so that an accurate dendrogram was not generated. Therefore, the dendrogram by primer $\mathrm{B} 1$ might not correspond to that of primer R28 and B9.

RAPD patterns were altered when a single nucleotide of primer B1 was substituted at successive 
Fig. 5. Dendrograms for RAPD patterns of 18 strains of Streptomyces lavendulae and Streptomyces virginiae.

(A) primer R28, (B) primer B1. These dendrograms were based on the 0-1 matrices obtained from Rf values of RAPD patterns (Fig. 4-A and B) and solved by the bootstrap search option contained within the PAUP (phylogenetic analysis using parsimony) phylogenetic inference package.

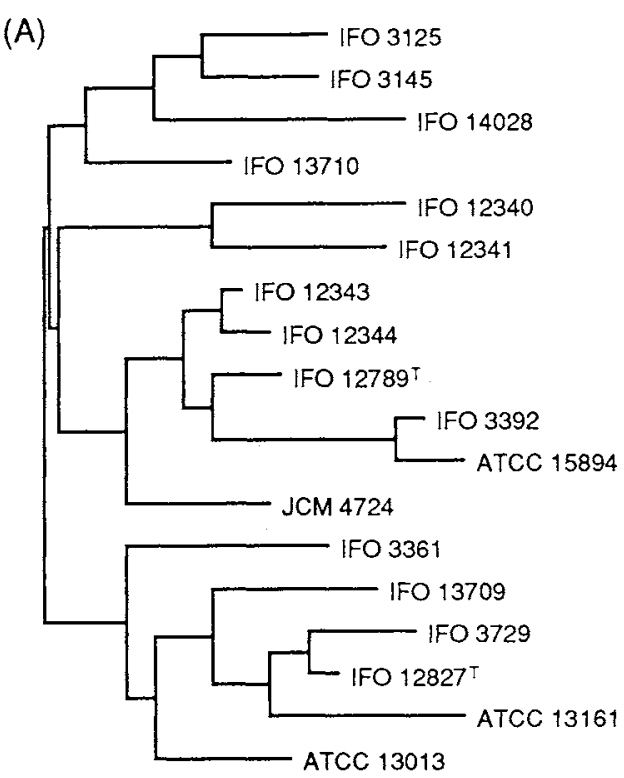

Fig. 6. RAPD patterns of $S$. lavendulae subsp. lavendulae IFO 12341 with primers B1 to B11.

$\mathrm{M}$ is pHY marker. Primer sequences: B1 (5'-TCACGATGCA), B2 (5'-ACACGATGCA), B3 (5'-TGACGATGCA), B4 (5'-TCTCGATGCA), B5 (5'-TCAGGATGCA), B6 (5'-TCACCATGCA), B7 (5'TCACGTTGCA), B8 (5'-TCACGAAGCA), B9 (5'-TCACGATCCA), B10 (5'-TCACGATGGA), BII (5'-TCACGATGCT).

\section{$\begin{array}{llllllllllllllllllllll}\text { M } & \text { B1 } & \text { B2 } & \text { B3 } & \text { B4 } & \text { B5 } & \text { B6 } & \text { B7 } & \text { B8 } & \text { B9 } & \text { B10 } & \text { B11 }\end{array}$}

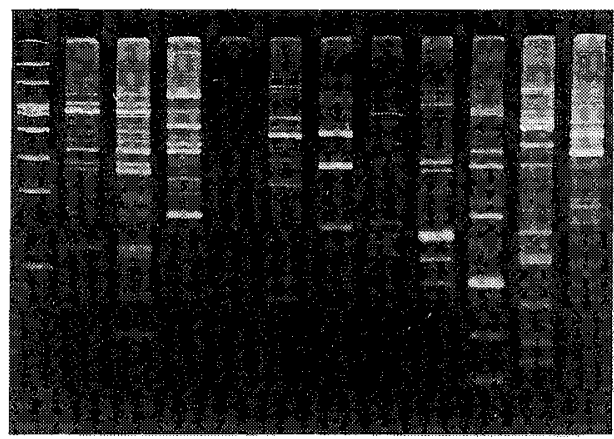

(B)

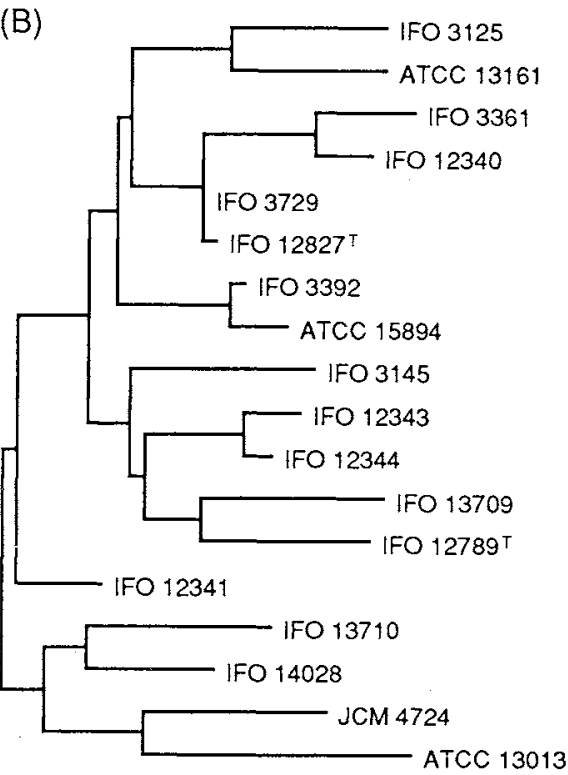

positions in the sequence with a constant $\mathrm{GC} \%$. Furthermore, a dramatic change was observed on the substitution from the third nucleotide, and primer B9 was found to be more suitable for RAPD analysis than primer B1. Therefore, the $3^{\prime}$ end sequences may be important for random amplification using the ten nucleotides primer.

In conclusion, since the following strains within each of the 3 groups were considered to be similar by RAPD analysis: $S$. lavendulae subsp. lavendulae IFO 12343, IFO 12344 and IFO 12789 S. virginiae IFO 3392 and ATCC 15894; S. virginiae IFO 3729 and IFO $12827^{\mathrm{T}}$, it was possible to select one strain from all similar strains.

Interestingly, it has been reported that $S$. lavendulae subsp. lavendulae IFO 12343, IFO 12344 and IFO $12789^{\mathrm{T}}$ produces streptothricin and $S$. virginiae IFO 3729 and IFO $12827^{\mathrm{T}}$ originated from the same strains. In addition, although WILLIAMs placed $S$. virginiae to a subjective synonym of $S$. lavendulae ${ }^{6}$, and AKIMov has reported that $S$. lavendulae group formed a single "genospecies"16), the homology value between $S$. lavendulae subsp.

lavendulae IFO $12789^{\mathrm{T}}$ and $S$. virginiae IFO $12827^{\mathrm{T}}$ was low in our study.

Therefore, we conclude that RAPD analysis with PCR is a simple, efficient, and reliable method. This method is a powerful tool for the elimination of duplicate actinomycete strains in microbial screenings. 
Purified DNA was used in all these experiments, however, the same results were obtained with crude or purified DNA.

\section{References}

1) Leblond, P.; F. X. Francou, J-M. Simonet \& B. Decaris: Pulsed-field gel electrophoresis analysis of the genome of Streptomyces ambofaciens strains. FEMS Microbiol. Lett. 72: 79 88, 1990

2) Ichiyama, S.; M. Ohta, K. Simokata, N. Kato \& J. Takeuchi: Genomic DNA fingerprinting by pulsed-field gel electrophoresis as an epidemiological marker for study of nosocomial infections caused by methicillin-resistant Staphylococcus aureus. J. Clin. Microbiol. 29: 2690 2695, 1991

3) Beyazova, M. \& M. P. Lechevalier: Low-frequency restriction fragment analysis of Frankia strains (Actinomycetales). Int. J. Syst. Bacteriol. 42: 422 433, 1992

4) McMilin, D. E. \& L. L. Muldrow: Typing of toxic strains of Clostridium difficile using DNA fingerprints generated with arbitrary polymerase chain reaction primers. FEMS Microbiol. Lett. 92: 5 10, 1992

5) MÉnard, C.; R. BRousseau \& C. MOUTON: Application of polymerase chain reaction with arbitrary primer (AP-PCR) to strain identification of Porphyromonas (Bacteroides) gingivalis. FEMS Microbiol. Lett. 95: $163 \sim 168,1992$

6) Williams, S. T.; M. Goodfellow \& G. Alderson: Genus Streptomyces Waksman and Henrichi $1943,339^{\mathrm{AL}}$. In BERGEY's Manual of Systematic Bacteriology. Volume 4, Ed., S. T. WiLliams et al., pp. 2452 2492, Williams \& Willkins Co., 1989

7) Shirling, E. B. \& D. Gottlieb: Methods for characterization of Streptomyces species. Int. J. Syst. Bacteriol. 16: $313 \sim 340,1966$

8) Marmur, J.: A procedure for the isolation of deoxyribonucleic acid from micro-organisms. J. Mol. Biol. 3: $208 \sim 218,1961$

9) EZAKI, T.; Y. HASHIMOTO \& E. YABUUCHI: Fluorometric deoxyribonucleic acid-deoxyribonucleic acid hybridization in microdilution wells as an alternative to membrane filter hybridization in which radioisotopes are used to determine genetic relatedness among bacterial strains. Int. J. Syst. Bacteriol. 39: 224 229, 1989

10) Frisvad, J. C. \& U. Thrane: Standardized high-performance liquid chromatography of 182 mycotoxins and other fungal metabolites based on alkylphenone retention indices and UV-VIS spectra (diode array detection). J. Chromatogr. 404: 195 214, 1987

11) KIESER, H. M.; T. KIESER \& D. A. Hopwood: A combined genetic and physical map of the Streptomyces coelicolor A3(2) chromosome. J. Bacteriol. 174: 5496 5507, 1992

12) Williams, J. G. K.; A. R. Kubelik, K. J. LivaK, J. A. Rafalski \& S. V. Tingey: DNA polymorphisms amplified by arbitrary primers are useful as genetic markers. Nucleic Acids Res. 18: 6531 6535, 1990

13) Goodwin, P. H. \& S. L. AnNis: Rapid identification of genetic variation and pathotype of Leptosphaeria maculans by random amplified polymorphic DNA assay. Appl. Environ. Microbiol. 57: 2482 2486, 1991

14) Fujmori, F. \& T. OKudA: Application of the random amplified polymorphic DNA using the polymerase chain reaction for ellimination of duplicate strains in microbial screening. I. Fungi. J. Antibiotics 47: 173 182, 1994

15) Swofford, D. L.: PAUP, phylogenetic analysis using parsimony, version 3.0s. Natural History Survery, Champaign, Illinois, U.S.A. 1991

16) Akimov, V. N.; E. V. Voevoda, T. F. Kuimova, S. D. Taptykova, I. V. Avraleva \& V. V. Zhunaeva: DNADNA hybridization and phage typing of Streptomycetes of the lavendulae group. Microbiology 60: 510 514, 1991 